\title{
STUDI TINDAKAN SOSIAL: TRADISI ZIARAH MAKAM NYI MAS GANDASARI DI DESA PANGURAGAN KABUPATEN CIREBON
}

\section{SOCIAL ACTION STUDY: THE TRADITION OF A VISIT TO NYI MAS GANDASARI SANCTUARY IN PANGURAGAN VILLAGE, CIREBON}

\author{
Maharani ${ }^{1}$ \\ IAIN Syekh Nurjati Cirebon \\ Ahmad Asmuni ${ }^{2}$ \\ IAIN Syekh Nurjati Cirebon \\ Burhanudin Sanusi $^{3}$ \\ IAIN Syekh Nurjati Cirebon
}

maharanisafitri95@yahoo.co.id

ahmadasmuni1158@gmail.com

burhanudin_sanusi@gmail.com

\begin{abstract}
ABSTRAK: Ziarah makam adalah salah satu bentuk budaya atau adat istiadat bagi sebagian masyarakat di Indonesia. Ziarah makam dilakukan dengan mengunjungi makam wali, para ulama, dan juga makam keluarga. Dalam penelitian ini bertujuan untuk mempelajari atau menganalisis terkait dengan tradisi masyarakat yang masih melestarikan tradisi ziarah ke makam Nyi Mas Gandasari. Penelitian ini menggunakan metode deskriptif kualitatif, fenomena yang diamati adalah kebiasaan masyarakat yang telah diturunkan dari leluhur terkait dengan ziarah ke makam Nyi Mas Gandasari. MHasil dan diskusi dalam penelitian ini. Pertama, terkait dengan sejarah makam Nyi Mas Gandasari, yang di klaim sebagai salah satu tempat persinggahan atau tempat pertapaan wali Allah ketika menyebarkan Islam di Cirebon. Jadi disitulah tempat peristirahatan terakhir Nyi Mas Gandasari. Kedua, selain bertujuan untuk mendoakan sang mayit, peziarah datang dengan motivasi yang berbeda-beda, seperti ingin meminta kesembuhan dari penyakit yang tidak bisa disembuhkan oleh medis, membawa harapan agar segera dipertemukan oleh jodohnya, ingin mendapat ketenangan, ingin usahanya lancar, pekerjaannya lancar, dll. Ketiga, bentuk-bentuk perilaku keagamaan peziarah terekspresikan ke dalam cara mereka mendoakan sang mayit, seperti tahlilan, istighosah, berdo'a, dll. Masyarakat Desa Panguragan pun masih melestarikan tradisi-tradisi lainnya, seperti muludan, ruwatan desa, hingga rutin berziarah ke makam Nyi Mas Gandasari.
\end{abstract}

Kata Kunci: Ziarah, Makam, Nyi Mas Gandasari.

ABSTRACT: Tomb pilgrimage is a form of culture or customs for some people in Indonesia. Tomb pilgrimages are carried out by visiting the graves of guardians, scholars, and also family graves. This study aims to study or analyze the traditions of the people who still preserve the tradition of pilgrimage to the tomb of Nyi Mas Gandasari. This study uses a qualitative descriptive method, the observed phenomenon is the habits of the people that have been passed down from their ancestors related to the pilgrimage to the tomb of Nyi Mas Gandasari. Results and discussion in this study. First, it is related to the history of Nyi Mas Gandasari's tomb, which is claimed to be a stopover or hermitage place for the guardian of Allah when spreading Islam in Cirebon. So that's where Nyi Mas Gandasari's final resting place is. Second, besides aiming to pray for the deceased, pilgrims come with different motivations, such as wanting to ask for healing from a disease that cannot be cured by medical treatment, bringing hope that their soul mate will soon meet their soul mate, wanting to find peace, wanting their business to run smoothly, work smoothly, etc. Third, the forms of religious behavior of pilgrims are expressed in the way they pray for the deceased, such as 
tahlilan, istighosah, prayer, etc. The community of Panguragan village also still preserves other traditions, such as muludan, village ruwatan, to routine pilgrimages to the grave of Nyi Mas Gandasari.

Keyword: Pilgrimage, Tomb, Nyi Mas Gandasari.

\section{A. PENDAHULUAN}

Tradisi ialah suatu kebiasaan yang dilakukan sejak lama dan secara terus menerus menjadi kehidupan masyarakat sampai saat ini. Tradisi merupakan kegiatan suatu kelompok masyarakat yang dilakukan berulang-ulang dan langgeng sifatnya. Tradisi secara umum dipahami sebagai pengetahuan, doktrin, kebiasaan yang diwariskan secara turun-temurun termasuk cara penyampaian pengetahuan, doktrin dan praktek tersebut. ${ }^{1}$ Setiap kelompok mempunyai tradisi yang berbeda. Hal ini didasarkan pada karakter masingmasing kelompok yang berbeda pula. Tradisi ada kalanya terbentuk oleh lingkungan di mana tradisi berada dan sudah terbentuk, kemudian diteruskan masyarakat karena hal tersebut merupakan peninggalan nenek moyang mereka. ${ }^{2}$ Tradisi ini biasanya berhubungan erat dengan unsur kepercayaan atau keagamaan yang memiliki makna moral yang penting. Biasanya dilakukan ditempat yang suci dan penting bagi keyakinan dan iman yang bersangkutan.

Tradisi di Indonesia, khususnya di masyarakat Jawa, merupakan sesuatu yang dianggap sakral, sehingga tradisi sangat dihormati serta dipertahankan oleh sebagian besar masyarakat Jawa. ${ }^{3}$ Sebagai contoh adalah tradisi ziarah makam yang ada di Jawa, tradisi tersebut dipertahankan karena masyarakat Jawa meyakini bahwa makam merupakan sebuah tempat suci yang mengandung aura yang berbeda dengan kekuatan tempat lainnya, sehingga penghormatan yang diberikan tentunya juga dapat berbeda-beda.

Ziarah makam merupakan tradisi yang telah mengakar pada masa pra-Islam dan kemudian berkembang sedemikian rupa ketika Islam berkembang di Nusantara. Ada relevansi ziarah makam wali dengan ziarah ke candi atau tempat lain pada masa praIslam. ${ }^{4}$ Ziarah makam tidak hanya merujuk pada ziarah makam wali atau tokoh agama, tetapi juga ziarah makam orang tua, pahlawan, kerabat, dan lain-lain. Ziarah bisa juga

\footnotetext{
${ }^{1}$ Anisatun Mutie ah, Harmonisasi Agama dan Budaya di Indonesia (Jakarta: Balai Penelitian dan Pengembangan Agama, 2009).

${ }^{2}$ Ahmad Amin, Ilmu Akhlak (Jakarta: Bulan Bintang, 1995).

${ }^{3}$ Nur Syam, Islam Pesisir (Yogyakarta: LKiS, 2005).

${ }^{4}$ Syam.
} 
dapat disebut sebagai ritual keagamaan karena di dalamnya mengkultuskan para leluhur atau nenek moyang yang telah meninggal. ${ }^{5}$

Secara garis besar, tujuan dari ziarah makam adalah untuk mengingatkan manusia bahwa kehidupan di dunia ini hanya sementara dan semua manusia akan mengalami kematian. ${ }^{6}$ Dengan berziarah makam dapat menjadikan diri manusia selalu mengingat akan kematian. Ziarah makam juga bisa dijadikan sebagai sarana untuk mengintropeksi diri tentang kematian yang pasti dialami oleh setiap yang berjiwa. ${ }^{7}$ Bagi sebagian masyarakat muslim, makam merupakan tempat yang dianggap suci dan pantas dihormati. Sebab makam merupakan tempat peristirahatan bagi arwah nenek moyang yang telah meninggal. Oleh sebabnya keberadaan makam dari tokoh tertentu dapat menimbulkan bermacam-macam daya tarik bagi masyarakat untuk melakukan aktivitas ziarah dengan berbagai motivasi pula. ${ }^{8}$

Tradisi ziarah makam juga erat hubungannya dengan kharisma leluhur yang makamnya banyak dikunjungi orang. Kharisma leluhur ini dapat diwujudkan dengan bentuk dan hiasan bangunan kubur/makam yang beraneka ragam, sesuai dengan tradisi seni bangun yang disukai atau dikuasai oleh masyarakat setempat. ${ }^{9}$ Hal ini pula yang terjadi pada fenomena ziarah makam ke Nyi Mas Gandasari. Kharisma dari sosok Nyi Mas Gandasari sebagai keturunan tidak langsung alias anak angkat Sunan Gunung Jati dan merupakan seorang Putri yang dianggap mempunyai keistimewaan yang luar biasa di mana ia dahulu menjadi satu-satunya panglima perang wanita dalam sejarah berdirinya kerajaan Cirebon. Jasa dari Nyi Mas Gandasari yang paling menonjol dan dikenang oleh masyarakat adalah karena Nyi Mas Gandasari berhasil membobol benteng pertahanan kerajaan Sunda Galuh pada masa lalu. Oleh sebab itulah nama Nyi Mas Gandasari selalu dikenang dan makamnya terus dilestarikan oleh masyarakat Desa Panguragan sampai pada saat ini. ${ }^{10}$

\footnotetext{
${ }^{5}$ M Mishabul Mujib, "Fenomena Tradisi Ziarah Lokal dalam Masyarakat Jawa: Kontestasi Kesalehan, Identitas Keagamaan dan Komersial," Ibda: Jurnal Kajian Islam dan Budaya 14, no. 2 (2016): 204-24.

${ }^{6}$ Purwadi, Jejak Para Wali dan Ziarah Spiritual (Jakarta: Kompas, 2006).

${ }^{7}$ Bahruddin Subkhy, Bid'ah-Bid'ah di Indonesia (Jakarta: Gema Insani Press, 1995).

${ }^{8}$ Hendra Kadarusman, "Tradisi Ziarah di Makam Aria Wangsa Goparana Dan Eyamg Dalem Ranggadipa di Kabupaten Subang” (UIN Sunan Gunung Djati, 2011).

${ }^{9}$ Feryani Umi Rosidah, Etnografi Ziarah Makam Sunan Ampel (Surabaya: IAIN Sunan Ampel Press, 2012).

${ }^{10}$ Bunaim, Juru Kunci makam Nyi Mas Gandasari, Wawancara, 27 November 2020
} 
Ziarah makam Nyi Mas Gandasari di Desa Panguragan adalah suatu warisan leluhur yang diturunkan secara turun temurun. Ziarah makam Nyi Mas Gandasari bisa disebut dengan ziarah makam terhadap nenek moyang. Sejak zaman dahulu masyarakat Desa Panguragan sangat mempercayai keberadaan leluhur mereka dan menganggap Nyi Mas Gandasari sebagai leluhur di desa mereka. ${ }^{11}$ Banyak peziarah makam Nyi Mas Gandasari yang tidak hanya berasal dari masyarakat desa Panguragan itu sendiri. Namun, ada juga peziarah makam dari luar desa yang datang dari berbagai daerah lainnya. Biasanya masyarakat Desa Panguragan mengunjungi makam Nyi Mas Gandasari pada saat-saat tertentu, misalnya pada waktu ruwatan desa, masa tanam (keleman) atau disebut dengan sedekah bumi. Sedangkan pengunjung makam yang berasal dari luar desa, umumnya mereka datang secara pribadi terkadang juga secara rombongan. ${ }^{12}$

Kondisi inilah yang membuat peneliti tertarik melakukan sebuah studi tindakan sosial terhadap fenomena ziarah di makam Nyi Mas Gandasari, dikarenakan sampai pada saat ini tradisi ziarah makam Nyi Mas Gandasari masih tetap dijalankan oleh masyarakat peziarah, baik oleh masyarakat desa maupun luar desa. Dalam penelitian ini, peneliti lebih menekankan pada tindakan sosial yang berupa bentuk perilaku dan bentuk motivasi yang dilakukan oleh peziarah.

\section{B. METODE PENELITIAN}

Jenis penelitian ini merupakan penelitian lapangan (field research), dalam penelitian ini peneliti menggunakan pendekatan penelitian kualitatif. Penelitian kualitatif adalah suatu metode yang bergantung dari pengamatan kepada suatu fenomena baik dalam kawasannya maupun peristilahannya. ${ }^{13}$ Teknik pengambilan data dalam penelitian ini adalah dengan cara wawancara, pengamatan, dan pemanfaatan dokumen. Sumber Data yang penulis peroleh ialah dari sumber data primer, yang mana data primer merupakan data yang diperoleh dari informan pertama atau pokok. Dalam hal ini peneliti menggunakan informan kuncen dan pengurus makam serta masyarakat yang berziarah ke makam Nyi Mas Gandasari. Adapun analisis data yang akan digunakan adalah dengan menggunakan teori tindakan sosial Max Weber.

\footnotetext{
${ }_{11}$ Arif, Kepala Desa Panguragan, Wawancara, Panguragan, 27 November 2020

${ }^{12}$ Nur, Masyarakat Desa Panguragan, Wawancara, Panguragan, 28 November 2020

${ }^{13}$ Sugiyono, Metode Penelitian Pendidikan (Pendekatan Kuantitatif, Kualitatif, dan R\&D) (Bandung: Alfabeta, 2010).
} 


\section{HASIL DAN PEMBAHASAN}

\section{Bentuk Perilaku Peziarah Nyi Mas Gandasari}

Tradisi yang masih dilestarikan oleh masyarakat Desa Panguragan dan sekitarnya, yakni tradisi ziarah makam. Tradisi ziarah makam Nyi Mas Gandasari tersebut dilakukan dalam bentuk perpaduan antara agama dan tradisi yang sudah menjadi hukum adat di Desa Panguragan Kabupaten Cirebon. Dari perpaduan tersebut, dalam tradisi ziarah hal yang paling dominan adalah tradisi Islam Jawa yang mempunyai banyak makna di dalamnya. Hal ini senada dengan pemikiran Max Weber yang mengatakan bahwa seseorang dalam bertindak tidak hanya sekedar melaksanakan dan konsep pendekatan ini lebih mengarah pada suatu tindakan bermotif pada tujuan yang hendak dicapai. ${ }^{14}$

Berdasarkan hal tersebut, Max Weber bermaksud menyatakan bahwa di dalam tindakan tercakup semua perilaku manusia asalkan pelakunya menyandangkan sebuah makna subjektif pada tindakan. Itu artinya Max Weber mengacu pada anggota-anggota masyarakat secara individual yang sedang melakukan sesuatu dengan sengaja atau dengan tujuan tertentu. Dia juga mengacu pada praktek-praktek anggota lain di dalam masyarakat yang bersangkutan dalam menyandang makna pada suatu tindakan untuk membuatnya menjadi sebuah tindakan yang bermakna. ${ }^{15}$ Jadi, dengan teori Max Weber tersebut menunjukkan bahwa ritual ziarah makam yang dilakukan oleh masyarakat merupakan ritual yang dilakukan dalam rangka untuk mendapatkan berkah dari seorang leluhur yang hidup sebelumnya yang dianggap berjasa sehingga perlu dimintai berkah dan petunjuk. ${ }^{16}$ Oleh sebab itu, tindakan tersebut bukanlah sekedar bertindak tapi lebih mengedepankan tujuan yang hendak dicapai, yaitu berkah. Selain itu karena dalam masyarakat Jawa masih mempunyai keyakinan-keyakinan terhadap tempat-tempat dan benda-benda yang dianggap memiliki kekuatan magic seperti, makam leluhur, pohon besar dan lain sebagainya. ${ }^{17}$

Dengan adanya suatu tujuan yang hendak dicapai, terbentuklah sikap yang dimiliki oleh manusia yang menghasilkan suatu tindakan. Perilaku tersebut

\footnotetext{
${ }^{14}$ Alfan Biroli, Drajat Tri Kartono, dan Argyo Demartoto, "Rasionalitas Wisatawan Wisata Pilgrim (Studi Fenomenologi Terhadap Wisatawan Di Kawasan Wisata Pilgrim Desa Gunungpring, Kecamatan Muntilan, Kabupaten Magelang),” Jurnal Analisa Sosiologi 4, no. 2 (2015): 60 -74.

15 Alis Muhlis dan Norkholis, "Analisis Tindakan Sosial Max Weber dalam Tradisi Pembacaan Kitab Mukhtashar Al-Bukhari (Studi Living Hadis),” Jurnal Living Hadis 1, no. 2 (2016): 243-58.

${ }^{16}$ Agus Muriawan Putra, "Identitas dan Komodifikasi Budaya dalam Pariwisata Budaya Bali," Analisis Pariwisata 8, no. 2 (2008): 7-17.

${ }^{17}$ Sardjuningsih, "Islam Mitos Indonesia (Kajian Antropologi-Sosiologi)," Kodifikasia 9, no. 1 (2015).
} 
diabstraksikan menjadi suatu norma. Norma atau kaidah berperan penting sebagai patokan tentang perilaku yang pantas. Norma itu kemudian mengatur interaksi antar manusia atau hubungan interpersonal. Tindakan sosial yang dilakukan oleh masyarakat ini merupakan norma sosial yang harus dilaksanakan setiap tahunnya dengan mengundang seluruh warga desa sendiri maupun luar desa untuk berinteraksi bersama-sama dengan istighosah dan tahlil bersama.

Selain teori di atas, Max Weber membagi tindakan sosial menjadi empat tipe antara lain rasionalitas instrumental, rasionalitas tujuan berorientasi, tindakan tradisional, dan tindakan efektif. ${ }^{18}$ Tindakan rasional instrumental merupakan tindakan yang dilakukan dengan mempertimbangkan tujuan dan alat yang digunakan untuk mencapai tujuan atau merupakan sebuah tindakan yang mencerminkan efektivitas dan efisiensi.

Selanjutnya, tipe yang kedua adalah tindakan rasional berorientasi. Tindakan sosial pada tipe ini, alat-alat hanya merupakan obyek perhitungan dan pertimbangan yang sadar, tetapi tujuannya sudah ada dalam hubungannya dengan nilai-nilai individu yang bersifat absolut yang sudah menjadi nilai akhir baginya. Tradisi ziarah makam Nyi Mas Gandasari yang dilakukan oleh masyarakat adalah tradisi leluhur yang sampai sekarang dilestarikan oleh generasi-generasinya. Masyarakat melakukan ziarah makam ini sesuai dengan apa yang dahulu sudah dilakukan oleh leluhur. Hal itu menunjukkan kalau tindakan ini dalam pandangan Weber merupakan suatu tindakan yang berada pada ranah non-rasional. ${ }^{19}$ Maksudnya adalah bahwa tindakan sosial dalam konteks hubungan sosial didasarkan pada tradisi-tradisi yang sudah dilaksanakan oleh nenek moyang kita, demikian juga nenek moyang mereka sebelumnya, ini merupakan suatu cara yang akan berkesinambungan.

Selanjutnya, tipe ketiga yaitu tindakan afektif merupakan tindakan yang dibuat-buat. Tindakan ini lebih didominasi perasaan atau emosi tanpa refleksi intelektual atau perencanaan sadar. Misalnya dalam memenuhi simbol-simbol atau perlengkapan pada ziarah makam Nyi Mas Gandasari juga merupakan tindakan afektif yang semua orang bisa melakukannya atau memenuhinya, tapi hal itu sangat

\footnotetext{
${ }^{18}$ Muhlis dan Norkholis, "Analisis Tindakan Sosial Max Weber dalam Tradisi Pembacaan Kitab Mukhtashar Al-Bukhari (Studi Living Hadis)."

${ }^{19}$ Ahmad Putra, "Konsep Agama dalam Perspektif Max Weber,” Al-AdYan 1, no. 1 (2020): 39-51.
} 
tidak rasional jika dilakukan. Misalnya, seperti membawakan makanan yang sudah ditentukan oleh kuncen, ketika peziarah mengharapkan sesuatu tetapi makanan yang diisyaratkan merupakan makanan yang mudah untuk didapatkan di lingkungan sekitar. Hal tersebut sangat tidak rasional karena jenis makanannya dapat dikatakan remeh, namun mempunyai pengaruh yang luar biasa, dan ketika harapan peziarah tidak terkabul maka perasaan emosional peziarah akan timbul sebagai sesuatu yang negatif.

Terakhir tindakan tradisional yaitu tindakan karena kebiasaan yang bertindak yang berkembang di masa lampau. Misalnya masyarakat dalam mengunjungi makam Nyi Mas Gandasari hanya berdasarkan pada tradisi-tradisi leluhur yang harus dilestarikan. Walaupun waktu terus berjalan sedemikian rupa atau yang kini biasa disebut sebagai era modern dalam artian zaman yang penuh dengan kecanggihan, tradisi ziarah makam Nyi Mas Gandasari masih tetap eksis sebagaimana yang dilakukan oleh masyarakat Desa Panguragan secara turun temurun.

Adat-istiadat atau tradisi yang dimiliki oleh masyarakat Desa Panguragan merupakan suatu kekayaan budaya, kebangsaan, dan berfungsi sebagai perendah hati dan cermin kepribadian suatu masyarakat atau suku adat sebagai identitas diri yang tak patut luntur tergerus zaman. Komunitas masyarakat memang harus memiliki identitas diri yang merupakan karakter dan jati diri agar mereka dapat diakui dan dihargai oleh lingkungannya. Sesuai dengan perkembangan zaman, rakyat biasapun sudah banyak yang berziarah ke makam-makam keluarganya yang telah meninggal. Pelaksanaan dan tata caranya juga telah banyak mengalami pergeseran. Hal itu terkait dengan sifat kebudayaan yang selalu berkembang dan mengalami perubahan zaman. Pada dasarnya pelaksanaan ziarah makam yang dijalankan oleh para pendukungnya memperlihatkan bahwa sistem pemujaan leluhur masih tetap hidup dan berkembang dalam kehidupan sosial budaya. ${ }^{20}$

\section{Motivasi Peziarah Makam Nyi Mas Gandasari}

Motivasi secara etimologi dapat dikatakan sebagai sesuatu atau alasan yang mendorong seseorang untuk melakukan tindakan atau perbuatan. Kata motivasi

\footnotetext{
${ }^{20}$ Syahdan, "Ziarah Perspektif Kajian Budaya (Studi Pada Situs Makam Mbah Priuk Jakarta Utara )," Jurnal Studi Agama dan Masyarakat 13, no. 1 (2017): 65-99.
} 
sendiri bisa dikatakan berasal dari bahasa Inggris, yaitu motive; it is a reason for doing something ${ }^{21}$ (alasan mengerjakan atau melakukan sesuatu). Sedangkan secara terminologi, motivasi didefinisikan sebagai tindakan atau perbuatan yang dilakukan oleh seseorang karena adanya dorongan atau rangsangan baik yang berasal dari dalam maupun luar orang itu.

Sejalan dengan definisi di atas, ahli psikologi mengatakan bahwa motivasi bisa muncul dari dalam diri seseorang atau karena sebab atau rangsangan dari luar. Oleh sebab itu, motivasi itu sendiri dibedakan menjadi dua, yaitu inner motive dan outer motive. Sesuai dengan istilahnya, inner motive merujuk kepada hal-hal yang berasal dari diri seseorang untuk melakukan sesuatu. ${ }^{22}$ Artinya, seseorang itu tidak perlu menunggu ada sebab atau respon dari luar dirinya. Sedangkan, outer motive adalah motivasi yang berasal dari luar diri seseorang. Artinya, seseorang itu melakukan sesuatu setelah menerima rangsangan atau merasakan sesuatu yang berasal dari luar diri sendiri. ${ }^{23}$

Berdasarkan definisi di atas, tradisi ziarah makam Nyi Mas Gandasari merupakan suatu kebiasaan yang sudah ada dan dipertahankan oleh masyarakat sekitar Desa Panguragan. Motivasi yang melatar belakangi para peziarah makam Nyi Mas Gandasari sangatlah bermacam-macam. Hal tersebut sesuai dengan apa yang telah disampaikan juru kunci makam yaitu bapak Bunaim yang mengatakan bahwa:

“...para peziarah di sini yang datang tujuannya berbeda-beda, tergantung dari niat dan keyakinannya masing-masing." 24

Dari wawancara di atas dapat dianalisis bahwa yang melatar belakangi tindakan orang-orang yang berziarah pada makam Nyi Mas Gandasari tidak bisa dikatakan homogen atau tunggal. Akan tetapi, motivasi yang melatar belakangi juga dapat bermacam-macam tergantung pada niat dan keyakinan orang yang berziarah. Secara normatif keagamaan, tujuan dari berziarah adalah agar orang yang hidup

\footnotetext{
${ }^{21}$ Laode Monto Bauto, "Perspektif Agama dan Kebudayaan dalam Kehidupan Masyarakat Indonesia (Suatu Tinjauan Sosiologi Agama),” JPIS, Jurnal Pendidikan Ilmu Sosial 23, no. 2 (2014): 11-25.

22 Tri Andjarwati, "Motivasi dari Sudut Pandang Teori Hirarki Kebutuhan Maslow, Teori Dua Faktor Herzberg, Teori X Y Mc Gregor, dan Teori Motivasi Prestasi McClelland,” JMM17 Jurnal Ilmu Ekonomi \& Manajemen 1, no. 1 (2015): 45-54.

${ }^{23}$ Rosidah, Etnografi Ziarah Makam Sunan Ampel.

${ }^{24}$ Wawancara dengan Kuncen, Bunaim di makam Nyi Mas Gandasari, 27 Januari 2021 pukul 10.40 WIB.
} 
mengingat kematian yang akan dialami atau dihadapi kelak. Hal tersebut juga tercantum pada niat dari sebagian para peziarah makam Nyi Mas Gandasari. Salah seorang peziarah bernama Ibu Nur mengatakan:

"Kalau masalah niat memang bermacam-macam mbak tapi kalau untuk saya pribadi, saya dan keluarga saya kesini memang berniat untuk mendekatkan diri pada Allah dengan mengingat kematian dan itu memang sudah menjadi kebiasaan kami pada malam sabtu kliwon memang selalu kesini untuk membaca yaasin dan tahlil." 25

Dari wawancara tersebut dapat dianalisis bahwa tradisi ziarah makam Nyi Mas Gandasari sudah menjadi suatu agenda tersendiri dalam rutinitas keagamaan para peziarah. Sebagaimana yang dinyatakan oleh Purwadi bahwa ziarah makam merupakan panggilan agama untuk mengingatkan pada dua hal, yaitu kehidupan orang yang diziarahi, dan akibat dari perbuatan yang dilakukan di hari kemudian. ${ }^{26}$ Oleh karena itu, sampai sekarang umat muslim maupun non-muslim masih melakukan tradisi ziarah ke makam menurut kepercayaannya masing-masing.

Secara sosiologis, motivasi orang untuk berziarah makam bisa dikatakan heterogen atau bermacam macam, bisa karena faktor kesehatan, faktor ekonomi dan pendidikan. ${ }^{27}$ Dalam hal kesehatan seperti mencari kesembuhan, mendapatkan ketenangan demi kesembuhan penyakit hati dan mendapat keselamatan dan keberkahan. Dalam hal ekonomi seperti untuk pariwisata, untuk mencari wangsit (contohnya meminta nomer togel) agar mendapatkan kemenangan dalam permainan togel, memenangkan proyek, dan mendapatkan pekerjaan. Dalam hal pendidikan seperti untuk penelitian ataupun untuk lulus Ujian Nasional. ${ }^{28}$

Hal tersebut serupa dengan apa yang terjadi di makam Nyi Mas Gandasari. Hal yang mendasari para peziarah untuk datang ke makam sangatlah beragam, selain karena tujuan normatif agama ataupun sekedar mengingat kematian, juga ada hal-hal lain yang menjadi motivasi para peziarah. Berdasarkan hasil wawancara yang dilakukan peneliti, para peziarah mengatakan bahwa mereka berziarah bukan untuk mengingat kematian akan tetapi juga motivasi lain, diantaranya:

\footnotetext{
${ }^{25}$ Wawancara dengan Nur, di kediaman rumahnya, Minggu, 27 Desember 2020, pukul 13.00 WIB

${ }^{26}$ Purwadi, Jejak Para Wali dan Ziarah Spiritual.

${ }^{27}$ Rosidah, Etnografi Ziarah Makam Sunan Ampel.

${ }^{28}$ Nur Faizah, "Tradisi Ziarah Makam Putri Terung di Desa Terung Wetan Kecamatan Krian Kabupaten Sidoarjo" (UIN Sunan Ampel Surabaya, 2014).
} 
Pertama, mencari ketenangan. Hal tersebut seperti yang diungkapkan oleh salah satu Informan yaitu bapak Saepul. Beliau mengatakan:

"Saya ini kalau dirumah kadang-kadang gak pernah tenang, karena saya orang yang suka seenaknya sendiri dan merasa frustasi. Saya selalu kesini untuk mencari ketenangan hidup." 29

Dari keterangan informan tersebut dapat dianalisis bahwa salah satu motivasi peziarah untuk datang ke makam Nyi Mas Gandasari adalah mencari ketenangan. Laki-laki yang berusia 28 tahun yang berasal dari Desa Plered tersebut mengaku bahwa meskipun sudah berkeluarga dia belum bisa mengontrol dirinya sendiri, sehingga sering sekali merasa frustasi ketika ada masalah. Menurut beliau salah satu solusi terbaik baginya adalah dengan berziarah ke makam-makam salah satunya makam Nyi Mas Gandasari karena berharap mendapatkan perenungan dan ketenangan.

Kedua, adalah mendapatkan kesembuhan. Mendapatkan kesembuhan ini termasuk ke dalam faktor kesehatan, karena peziarah datang ke makam disebabkan ingin mencari kesembuhan dan kesehatan. Hal tersebut seperti yang diungkapkan oleh salah satu informan yaitu Ibu Eti. Beliau mengatakan:

"Para peziarah makam ini niatnya sangat bervariasi mbak. Salah satunya adalah untuk mencari kesembuhan dengan ketika pulang membawa air dari sumur kesembuhan yang terletak di depan makam, termasuk saya. Kadangkadang kalau saya atau keluarga saya sakit selalu saya bawakan air sumur itu dan sembuh, tetapi terlebih dahulu ziarah ke makam Nyi Mas Gandasari."

Dari wawancara tersebut dapat dijabarkan bahwa mendapatkan kesembuhan adalah merupakan salah satu faktor motivasi orang berziarah ke makam Nyi Mas Gandsari. Ibu Eti mengaku bahwa tidak hanya penyakit karena virus atau penyakit karena bakteri yang bisa disembuhkan dengan meminum air sumur makam Nyi Mas Gansadari. Akan tetapi, penyakit yang disebabkan karena ilmu hitam (santet) juga bisa disembuhkan.

Ibu Eti menceritakan bahwa anaknya pernah mengalami sakit, ketika dibawa ke dokter dan diperiksa tidak terjangkit penyakit apapun yang dideritanya. Namun, anak ini terus merasakan kesakitan di perutnya, sehingga akhirnya beliau berziarah ke makam Nyi Mas Gandasari dan mengambil air sumur tersebut untuk

\footnotetext{
${ }^{29}$ Wawancara dengan Saipul, di makam Nyi Mas Gandasari, Rabu, 13 Januari 2021 pukul 15.00 WIB

${ }^{30}$ Wawancara dengan Eti, di makam Nyi Mas Gandasari, Rabu, 27 Januari 2021 pukul 11.30 WIB
} 
diminumkan kepada anaknya. Dari penuturan Ibu Eti, temannya tersebut sampai sekarang sudah tidah kambuh lagi.

Ketiga, adalah mendapatkan jodoh. Hal tersebut seperti yang diungkapkan oleh salah satu pengunjung makam bernama Misnen, ia mengatakan:

"Saya datang ke makam ini, karena saya mendengar bahwa makam ini mempunyai sumber air yang dipercaya memiliki kesaktian untuk mencarikan jodoh. Saya membawa anak sulung saya yang bernama Dita kemudian setelah tiga bulan pasca Dita dimandikan di salah satu sumur yang ada di makam Nyi Mas Gandasari, Alhamdulillah akhirnya anak saya menemukan jodohnya mbak."31

Dari wawancara tersebut dapat dijabarkan bahwa mendapatkan jodoh adalah merupakan salah satu faktor motivasi orang berziarah ke makam Nyi Mas Gandsari. Salah satu sumur yang ada di makam Nyi Mas Gandasari ini dipercaya ampuh untuk mendatangkan jodoh dengan cara orang yang ingin meminta jodoh ini harus mau dimandikan di salah satu sumur yang ada di makam Nyi Mas Gandasari ini dengan syarat membawa bunga tujuh rupa sebagai wujud ritualnya. Atau biasa dikenal dengan istilah mandi kembang.

Keempat, mendapat keselamatan dan keberkahan. Hal tersebut seperti yang diungkapkan oleh bapak Mustadi, beliau mengatakan:

"Memang adat disini itu, mbak. Siapa saja yang punya hajat misalnya pernikahan atau khitanan atau acara-acara apapun, harus datang ke makam Nyi Mas dulu agar acaranya dapat berjalan dengan lancar, itu sudah dipercayai masyarakat sini sebagai ngalap barokah lan keselamatan. Misalnya kalau pernikahan biar penikahannya barokah diberikan kebahagiaan dan keselamatan, mbak." ${ }^{32}$

Dari keterangan bapak Mustadi tersebut dapat dianalisis bahwa memang salah satu faktor penentu dari para peziarah untuk datang ke makam Nyi Mas Gandasari bisa disebabkan karena kepercayaan mereka yang sejak turun temurun dilestarikan yaitu adat ngalap barokah lan keselamatan.

Adat ngalap barokah lan keselamatan adalah suatu tradisi ziarah makam yang kedatangannya diniatkan untuk mengharap barokah dan keselamatan, misalnya kalau ada hajat pernikahan atau khitanan dan acara- acara lain yang berhubungan dengan kebahagiaan seperti panen padi, panen tebu atau kelahiran

\footnotetext{
${ }^{31}$ Wawancara dengan Misnen di makam Nyi Mas Gandasari, Kamis, 24 Desember 2020, pukul 10.30 WIB

${ }^{32}$ Wawancara dengan Mustadi, di makam Nyi Mas Gandasari, Rabu, 27 Januari 2021 pukul 11.00 WIB
} 
seorang bayi, dan lain-lain dengan membawa tumpeng yang sudah dipersiapkan. Salah satu upacara adat yang dilakukan adalah yang disebut sebagai upacara sedekah bumi yaitu upacara yang dilakukan di makam Nyi Mas Gandasari untuk mengucapkan rasa syukur karena telah panen padi.

\section{SIMPULAN}

Asal-usul tradisi ziarah makam Nyi Mas Gandasari bermula ketika Nyi Mas Ratu Gandasari meninggal, awalnya hanya orang-orang tertentu saja yang mengunjungi makam, seperti orang-orang di padepokan tersebut, mulai dari murid-muridnya, pelayanpelayan hingga orang biasa yang tinggal disitu. Lambat laun akhirnya pengunjung makam semakin bertambah karena sudah banyak yang mengetahui tentang legenda Nyi Mas Gandasari, legenda tersebut menyatakan bahwa ia adalah satu-satunya panglima perang wanita yang memiliki paras cantik nan kesaktian yang luar biasa. Hingga pada akhirnya, banyak orang yang dari luar daerahpun berbondong-bondong mengunjungi makam tersebut.

Yang menjadi motivasi peziarah ialah kebanyakan ingin mendapatkan karamah dari kharisma leluhur yakni Nyi Mas Ratu Gandasari. Tetapi tidak hanya itu peziarah juga membawa harapan-harapan kecil lainnya seperti mengharapkan kesembuhan dari penyakit yang tidak bisa disembuhkan oleh medis, mengharapkan agar dipermudah ketemu jodoh, mengharapkan agar usahanya lancar, pekerjaan lancar dan mencari ketenangan hidup. Bentuk-bentuk perilaku keagamaan peziarah dapat terlihat ketika ia mengunjungi makam, mendoakan sang mayit, melakukan tahlilan, istighosah, bahkan bukan hanya peziarah saja tetapi pengurus makam juga setiap hari melakukan doa bersama setiap malamnya hingga larut malam. Bentuk-bentuk keagamaan lainnya terlihat bahwa masyarakat desa tersebut masih melestarikan tradisi-tradisi yang ada seperti muludan, ruwatan desa, sedekah bumi, hingga ziarah makam ke sesepuh mereka yakni Nyi Mas Ratu Gandasari.

Bagi sebagian masyarakat peziarah, kegiatan ziarah makam terhadap makam para wali dan ulama, seperti makam Nyi Mas Gandasari merupakan kegiatan yang sudah mengakar dalam jiwa masyarakat Islam Jawa. Sehingga hal tersebut sulit dihilangkan, karena sudah menjadi tradisi dan membudaya dalam kalangan masyarakat Islam Jawa. Akan tetapi bagi masyarakat peziarah harus menata hati lebih dalm-dalam saat berziarah supaya tidak 
terjerumus dalam lembah ke musyrikan yang dapat merusak akidah serta agama. Oleh sebab itu, hal tersebut harus benar-benar dijaga dan diperhatikan dengan sebenar-benarnya.

\section{DAFTAR PUSTAKA}

Amin, Ahmad. Ilmu Akhlak. Jakarta: Bulan Bintang, 1995.

Andjarwati, Tri. "Motivasi dari Sudut Pandang Teori Hirarki Kebutuhan Maslow, Teori Dua Faktor Herzberg, Teori X Y Mc Gregor, dan Teori Motivasi Prestasi McClelland.” JMM17 Jurnal Ilmu Ekonomi \& Manajemen 1, no. 1 (2015): 45-54. Bauto, Laode Monto. "Perspektif Agama dan Kebudayaan dalam Kehidupan Masyarakat Indonesia (Suatu Tinjauan Sosiologi Agama).” JPIS, Jurnal Pendidikan Ilmu Sosial 23, no. 2 (2014): 11-25.

Biroli, Alfan, Drajat Tri Kartono, dan Argyo Demartoto. "Rasionalitas Wisatawan Wisata Pilgrim (Studi Fenomenologi Terhadap Wisatawan Di Kawasan Wisata Pilgrim Desa Gunungpring, Kecamatan Muntilan, Kabupaten Magelang).” Jurnal Analisa Sosiologi 4, no. 2 (2015): 60 -74.

Faizah, Nur. "Tradisi Ziarah Makam Putri Terung di Desa Terung Wetan Kecamatan Krian Kabupaten Sidoarjo.” UIN Sunan Ampel Surabaya, 2014.

Kadarusman, Hendra. "Tradisi Ziarah di Makam Aria Wangsa Goparana Dan Eyamg Dalem Ranggadipa di Kabupaten Subang.” UIN Sunan Gunung Djati, 2011. Muhlis, Alis, dan Norkholis. “Analisis Tindakan Sosial Max Weber dalam Tradisi Pembacaan Kitab Mukhtashar Al-Bukhari (Studi Living Hadis).” Jurnal Living Hadis 1, no. 2 (2016): 243-58.

Mujib, M Mishabul. "Fenomena Tradisi Ziarah Lokal dalam Masyarakat Jawa:

Kontestasi Kesalehan, Identitas Keagamaan dan Komersial.” Ibda: Jurnal Kajian Islam dan Budaya 14, no. 2 (2016): 204-24.

Mutieeah, Anisatun. Harmonisasi Agama dan Budaya di Indonesia. Jakarta: Balai

Penelitian dan Pengembangan Agama, 2009.

Purwadi. Jejak Para Wali dan Ziarah Spiritual. Jakarta: Kompas, 2006.

Putra, Agus Muriawan. “Identitas dan Komodifikasi Budaya dalam Pariwisata Budaya Bali.” Analisis Pariwisata 8, no. 2 (2008): 7-17.

Putra, Ahmad. "Konsep Agama dalam Perspektif Max Weber.” Al-AdYan 1, no. 1 (2020): 39-51.

Rosidah, Feryani Umi. Etnografi Ziarah Makam Sunan Ampel. Surabaya: IAIN Sunan 
YAQZHAN | Volume 07, Nomor 02, Desember 2021

Ampel Press, 2012.

Sardjuningsih. "Islam Mitos Indonesia (Kajian Antropologi-Sosiologi).” Kodifikasia 9, no. $1(2015)$.

Subkhy, Bahruddin. Bid'ah-Bid'ah di Indonesia. Jakarta: Gema Insani Press, 1995. Sugiyono. Metode Penelitian Pendidikan (Pendekatan Kuantitatif, Kualitatif, dan $R \& D)$. Bandung: Alfabeta, 2010.

Syahdan. "Ziarah Perspektif Kajian Budaya (Studi Pada Situs Makam Mbah Priuk Jakarta Utara ).” Jurnal Studi Agama dan Masyarakat 13, no. 1 (2017): 65-99. Syam, Nur. Islam Pesisir. Yogyakarta: LKiS, 2005. 